\title{
Economic and Horticultural Evaluation of Chemical and Mechanical Weed Control Strategies for Cowpea
}

\author{
Brian A. Kahn' ${ }^{1}$ and Raymond Joe Schatzer ${ }^{2}$ \\ Oklahoma State University, Stillwater OK 74078 \\ Additional index words. Vigna unguiculata, budgets, cultivation, herbicides, income, metolachlor, paraquat, trifluralin
}

\begin{abstract}
The herbicides paraquat, trifluralin, and metolachlor were compared for efficacy of weed control in cowpea [Vigna unguiculata (L.) Walp.] with and without cultivation as a supplemental strategy. Herbicides also were compared against a no cultivation-no herbicide treatment (control) and against cultivation without an herbicide. Cultivation had no significant effect on seed yield, biological yield, or harvest index of cowpea. Paraquat, applied before seeding but after emergence of weeds, was ineffective for weed control and usually did not change cowpea yield from that obtained without an herbicide. Trifluralin and metolachlor more than tripled cowpea seed yield compared with that obtained without an herbicide in 1988 , when potential weed pressure was $886 \mathrm{~g} \cdot \mathrm{m}^{-2}$ (dry weight). The main effects of trifluralin and metolachlor were not significant for cowpea seed yield in 1989, when potential weed pressure was $319 \mathrm{~g} \cdot \mathrm{m}^{-2}$ (dry weight). However, in 1989, these two herbicides still increased cowpea seed yield compared with that of the control and increased net farm income by more than $\$ 300 /$ ha compared with the income obtained from the control. Chemical names used 1,1'-dimethyl-4,4' -bipyridlnium salts (paraquat); 2,6-dinitro-N,N-dipropyl-4-(trifluoromethyl) benzenamine (trifluralin); 2-chloro-N-(2-ethyl-6 -methylphenyl)-N- (2-methoxy-l-methylethyl) acetamide (metolachlor).
\end{abstract}

Weed control is an important aspect of cowpea production. Uncontrolled weed growth reduces cowpea seed yield by up to $70 \%$ (Ofuya, 1989). Manual weeding may provide adequate weed control, but the increasing cost and reduced availability of field labor often make manual weeding inefficient and uneconomical (Akobundu, 1982). Therefore, many growers use herbicides. Trifluralin (Glaze, 1970) and metolachlor (Akobundu, 1982) are effective herbicides for cowpea weed control. Paraquat also can be used in a "stale seedbed" system (Standifer and Beste, 1985) to control emerged weeds. However, all three of these herbicides are under re-registration review by the U.S. Environmental Protection Agency.

Formal pesticide benefit assessments do not generally contain detailed economic analyses of alternative, nonchemical pest control strategies (National Research Council, 1989). There is renewed interest in cultivation as a "low-input" alternative to chemical weed control. Cultivation-based weed control strategies have been successfully used in corn [Zea mays var. indentata (Sturtev.) L.H. Bailey] and soybean IGlycine mux (L.) Merrill] (National Research Council, 1989).

The objective of this study was to compare paraquat, trifluralin, and metolachlor for efficacy of weed control in cowpea with and without mechanical cultivation as a supplemental strategy. Herbicide treatments also were compared to cultivation alone and to a control with no cultivation and no herbicide. An economic analysis was conducted to determine the net change

Received for publication 18 Mar. 1991. Accepted for publication 27 Sept. 1991 Journal Article no. J-5970 of the Agr. Expt. Sta., Oklahoma State Univ., Stillwater. Funded in part by Grant no. SR88-03-W-OK from the Southern Region Pesticide Impact Assessment Program. The authors thank Wendy A. Nelson and Bruce Bostian for technical assistance with the field experiments. The information given in this publication is for educational purposes only. Mention of a trademark, proprietary product, or vendor does not constitute a guarantee or warranty of the product, nor does it imply approval or disapproval to the exclusion of other products or vendors that may also be suitable. The cost of publishing this paper was defrayed in part by the payment of page charges. Under postal regulations, this paper therefore must be hereby marked adverdsement solely to indicate this fact.

'Associate Professor, Dept. of Horticulture and Landscape Architecture. ${ }^{2}$ Associate Professor, Dept. of Agricultural Economics. in per-hectare income resulting from the use of herbicides, cultivation, or both to control weeds.

\section{Materials and Methods}

Field experiments were conducted at the Vegetable Research Station, Bixby, Okla., during 1988 and 1989. The soil was a Severn very fine sandy loam [coarse-silty, mixed (calcareous), thermic Typic Udifluvent]. The soil was plowed and prepared with a broadcast, preplant-incorporated application of urea to provide $34 \mathrm{~kg}$ N/ha each year. Adequate $\mathrm{P}$ and $\mathrm{K}$ were available from fertilization of previous trials. The 1989 study was located adjacent to the field used for the 1988 study so that herbicide carry-over would not be a factor.

A split-block treatment design arranged in randomized complete blocks with four replications was used. Main plots were cultivation treatments: an uncultivated control; one cultivation at the time the first trifoliolate leaf was fully expanded on all plants; and two cultivations, one at the first trifoliolate stage and a second at anthesis (all plants with one or more blossoms). Subplots were herbicide treatments applied in strips across an entire block of cultivation plots: a no-herbicide control; preplant-incorporated trifluralin at $0.56 \mathrm{~kg} \cdot \mathrm{ha}^{-1}$; preplant-incorporated metolachlor at $1.68 \mathrm{~kg} \cdot \mathrm{ha}^{-1}$; and paraquat at $0.84 \mathrm{~kg} \cdot \mathrm{ha}^{-1}$ applied preplant but postemergence to weeds ("stale seedbed").

A tractor-powered boom sprayer with a spray volume of 262 liters.ha ${ }^{-1}$ applied herbicides to the soil surface in a water carrier on 7 July 1988 (Expt. 1) and 16 June 1989 (Expt. 2). A surfactant (X-77, Valent USA, Walnut Creek, Calif.) at $0.5 \%$ $\mathrm{v} / \mathrm{v}$ was tank-mixed with the paraquat. No adjuvants were used with trifluralin or metolachlor. A tractor-mounted power tiller incorporated the trifluralin and metolachlor immediately after application to a depth of $\approx 7 \mathrm{~cm}$. Control plots also were tilled, but the paraquat plots were left undisturbed in accordance with the stale seedbed technique.

Experimental units consisted of four-row plots that were $4 \mathrm{~m}$ long. Rows were $55 \mathrm{~cm}$ apart, with the two center rows used for data collection. Seeds of 'Epoch' cowpea were sown with a Planet Jr. Model 300A unit (Powell Manufacturing, Bennettsville, S.C.) on 8 July 1988 at 10 seeds/m of row. Germination 
percentages were lower than expected, so the seeding rate was increased to 15 seeds/m of row in 1989 to ensure the desired stand of nine to 10 plants/m of row. The 1989 planting date was 19 June. Weak, diseased, or excessively crowded seedlings were removed on 18 July 1988 and 28 June 1989, and postthinning stand counts were made.

A high-clearance row-crop tractor equipped with three $35-\mathrm{cm}$ sweeps was used for cultivation. One sweep ran at $\approx 28 \mathrm{~cm}$ on each side of each data row per pass of the tractor. The sweeps ran at an average depth of $5 \mathrm{~cm}$. Cultivation dates were 22 July and 12 Aug. 1988, and 5 and 25 July 1989.

Plots were irrigated based on subjective soil observations using portable aluminum pipe and overhead sprinklers. Eight irrigations were applied in 1988 (total of $85 \mathrm{~mm}$ water); six were applied in 1989 (total of $55 \mathrm{~mm}$ water).

Insects were controlled with methyl N-[[(methylamino)carbonyl]-oxy] ethanimidothioate (methomyl) that was applied at $500 \mathrm{~g} \cdot \mathrm{ha}^{-1}$ on $22 \mathrm{July} 1988$, at $1000 \mathrm{~g} \cdot \mathrm{ha}^{-1}$ on $24 \mathrm{June}$ 1989, and at $500 \mathrm{~g} \cdot \mathrm{ha}^{-1}$ on 2 July 1989.

Plots were hand-harvested by replication 15-17 Sept. 1988 and 31 Aug.-1 Sept. 1989, when most of the pods were dry. Data were collected from the middle $2 \mathrm{~m}$ of each $4-\mathrm{m}$ plot. First, all tall weeds in this area were cut off at soil level, counted, and bagged. The three primary tall weed species were pigweeds (chiefly Amaranthus retroflexus L.), goosegrass [Eleusine indica (L.) Gaertn.], and large crabgrass [Digitaria sanguinalis (L.) Stop.]. Next, all cowpea plants in the data collection area were cut off at soil level, counted, and bagged. Finally, all remaining weeds in the data area (primarily carpetweed, Mollugo verticillata L.) were cut off and combined with those previously harvested. Unabscised leaves were removed from the cowpea plants. Plant stems, pods, and seeds were dried at 55C for at least 4 days before being weighed. A random sample of 100 undamaged seeds was weighed to determine average weight per individual seed. The harvest index was taken as (seed yield/ biological yield) $\times 100$.

Data were evaluated by an analysis of variance. Main effects of cultivation were partitioned into single-degree-of-freedom orthogonal contrasts. Mean separation between herbicide treat- ments was performed where appropriate by Duncan's multiple range test (DMRT) at $P=0.05$. Mean seed yields from individual treatments also were separated by least significant difference (LSD) at $P=0.05$ to facilitate economic evaluation.

The partial budgeting technique was used for economic evaluation. The partial budgets show the change in net farm income between the control (no cultivation or herbicide) and selected treatments. Prices for the various inputs were based on information obtained from dealers and surveys of custom machinery operators. The cost of the machine operation for final tilling of the control plots and the incorporation of trifluralin or metolachlor was $\$ 12.35 / \mathrm{ha}$. The cost of cultivation also was $\$ 12.35$ / ha. Spraying the chemicals required $\$ 7.40 /$ ha. Operating capital costs were $\$ 0.025$ per dollar of preharvest costs. Custom mechanical harvest was assumed at a cost of $\$ 39.55 /$ ha, irrespective of yield. The cost of hauling cowpeas was increased by $\$ 4.40 / \mathrm{Mg}$ extra seed yield. The selling price for cowpeas was $\$ 600 / \mathrm{Mg}$. The cost of the chemical materials was $\$ 46.30 / \mathrm{kg}$ for paraquat, $\$ 17.64 / \mathrm{kg}$ for trifluralin, $\$ 15.98 / \mathrm{kg}$ for metolachlor, and $\$ 10.58 /$ liter for methomyl. Other costs are detailed in Table 4.

\section{Results and Discussion}

Horticultural aspects. An analysis showed no differences in cowpea stands after thinning or at harvest in 1988 (data not presented). Average stands were 12 plants $/ \mathrm{m}^{2}$ after thinning and at harvest in 1988. There were no differences in cowpea stands after thinning in 1989, with an average of 18 plants $/ \mathrm{m}^{2}$ (data not presented). However, the main effect of herbicide treatment was significant $(P=0.01)$ for stand at harvest in 1989. Average stands (plants $/ \mathrm{m}^{2}$ ), with mean separation by DMRT, were: control $=18 \mathrm{a}$; paraquat $=18 \mathrm{a}$; trifluralin $=17 \mathrm{~b}$; and metolachlor $=16 \mathrm{c}$. This finding is not readily explained. There was no evidence of herbicide toxicity to the cowpeas in 1988 or during stand establishment in 1989. It appears that some of the seedlings present after thinning in 1989 were too weak to survive until harvest. Also, metolachlor might have been less injurious if it had been applied preemergence rather than preplant-incorporated. Akinyemiju and Echendu (1987) observed

Table 1. Effects of mechanical and chemical weed control strategies on cowpea yield and weed control, 1988.

\begin{tabular}{|c|c|c|c|c|c|c|}
\hline Treatment & $\begin{array}{c}\text { Biological } \\
\text { yield } \\
\left(\mathrm{Mg} \cdot \mathrm{ha}^{-1}\right)\end{array}$ & $\begin{array}{c}\text { Seed } \\
\text { yield } \\
\left(\mathrm{Mg} \cdot \mathrm{ha}^{-1}\right)\end{array}$ & $\begin{array}{c}\text { Harvest } \\
\text { index } \\
(\%)\end{array}$ & $\begin{array}{c}\text { Individual } \\
\text { seed wt } \\
(\mathrm{mg} / \mathrm{seed})\end{array}$ & $\begin{array}{c}\text { Weed } \\
\text { dry wt } \\
\left(\mathrm{g} \cdot \mathrm{m}^{-2}\right)\end{array}$ & $\begin{array}{l}\text { Pigweeds } \\
\text { (no. } / \mathrm{m}^{2} \text { ) }\end{array}$ \\
\hline \multicolumn{7}{|l|}{ Cultivations (C) } \\
\hline 0 & 2.08 & 1.01 & 46.8 & 154 & 450 & 2.3 \\
\hline 1 & 2.20 & 1.07 & 48.3 & 164 & 312 & 1.7 \\
\hline 2 & 2.33 & 1.13 & 47.9 & 163 & 222 & 0.8 \\
\hline Control vs. C & NS & NS & NS & NS & w & NS \\
\hline 1 vs. $2 \mathrm{C}$ & NS & NS & NS & NS & w & NS \\
\hline \multicolumn{7}{|l|}{ Herbicide $(\mathrm{H})^{\mathrm{v}}$} \\
\hline None & $1.03 \mathrm{~b}$ & $0.49 \mathrm{~b}$ & $46.4 \mathrm{bc}$ & $149 \mathrm{~b}$ & 653 & $4.0 \mathrm{a}$ \\
\hline Paraquat & $1.22 \mathrm{~b}$ & $0.57 \mathrm{~b}$ & $46.0 c$ & $152 \mathrm{~b}$ & 635 & $4.0 \mathrm{a}$ \\
\hline Trifluralin & $3.40 \mathrm{a}$ & $1.67 \mathrm{a}$ & $49.2 \mathrm{a}$ & $170 \mathrm{a}$ & 5 & $<0.1 \mathrm{~b}$ \\
\hline Mctolachlor & $3.15 \mathrm{a}$ & $1.55 \mathrm{a}$ & $49.0 \mathrm{ab}$ & $172 \mathrm{a}$ & 18 & $0.1 \mathrm{~b}$ \\
\hline Main effect & $* *$ & $* *$ & $*$ & $*$ & w & $* *$ \\
\hline
\end{tabular}

${ }^{2}$ Dry weight of stems, podwalls, and seeds.

y Harvest index $=($ seed yield/biological yield $) \times 100$.

xAmaranthus sp.; primarily $A$. retroflexus $\mathrm{L}$. Data transformed with $(\mathrm{x}+0.5)^{1 / 2}$ before analysis. Back-transformed means are shown.

"Significant $(P=0.01) \mathrm{C} \times \mathrm{H}$ interaction.

"Mean separation in columns by Duncan's multiple range test, $P=0.05$.

NS,*,**Nonsignificant or significant at $P=0.05$ or 0.01 , respectively. 
Table 2. Effects of mechanical and chemical weed control strategies on cowpea yield and weed control, 1989.

\begin{tabular}{|c|c|c|c|c|c|c|}
\hline Treatment & $\begin{array}{c}\text { Biological } \\
\text { yieldz } \\
\left(\mathrm{Mg} \cdot \mathrm{ha}^{-1}\right)\end{array}$ & $\begin{array}{c}\text { Seed } \\
\text { yield } \\
\left(\mathrm{Mg} \cdot \mathrm{ha}^{-1}\right)\end{array}$ & $\begin{array}{c}\text { Harvest } \\
\text { index } \\
(\%)\end{array}$ & $\begin{array}{l}\text { Individual } \\
\text { seed wt } \\
(\mathrm{mg} / \mathrm{seed})\end{array}$ & $\begin{array}{c}\text { Weed } \\
\text { dry wt } \\
\left(\mathrm{g} \cdot \mathrm{m}^{-2}\right)\end{array}$ & $\begin{array}{l}\text { Pigweeds } \\
\text { (no. } / \mathrm{m}^{2} \text { ) }\end{array}$ \\
\hline \multicolumn{7}{|l|}{ Cultivations (C) } \\
\hline 0 & 4.18 & 1.45 & 31.0 & 178 & 224 & 0.9 \\
\hline 1 & 4.84 & 1.71 & 34.5 & 175 & 59 & 0.2 \\
\hline 2 & 4.76 & 1.72 & 34.7 & 184 & 39 & 0.2 \\
\hline Control vs. C & NS & NS & NS & NS & $w$ & NS \\
\hline $\begin{array}{l}1 \text { vs. } 2 \mathrm{C} \\
\text { Herbicide }(\mathrm{H})^{v}\end{array}$ & \multicolumn{3}{|c|}{ Herbicide $(\mathrm{H})^{\mathrm{v}}$} & NS & w & NS \\
\hline No herbicide & 4.65 & $1.48 \mathrm{ab}$ & $29.2 \mathrm{~b}$ & 172 & 144 & 1.0 \\
\hline Paraquat & 3.81 & $1.23 \mathrm{~b}$ & $28.6 \mathrm{~b}$ & 179 & 284 & 0.8 \\
\hline Trifluralin & 5.02 & $1.88 \mathrm{a}$ & $37.2 \mathrm{a}$ & 184 & 0.3 & 0.1 \\
\hline Metolachlor & 4.91 & $1.91 \mathrm{a}$ & $38.7 \mathrm{a}$ & 182 & $<0.1$ & 0.0 \\
\hline Main effect & NS & 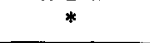 & $*$ & NS & $w^{v .1}$ & NS \\
\hline
\end{tabular}

${ }^{2}$ Dry weight of stems, podwalls, and seeds.

${ }^{y}$ Harvest index $=($ seed yield/biological yield $) \times 100$.

xAmaranthus sp.; primarily $A$. retroflexus L. Data transformed with $(\mathrm{x}+0.5)^{1 / 2}$ before analysis. Back-transformed means are shown.

"Significant $(P=0.05) \mathrm{C} \times \mathrm{H}$ interaction.

vMean separation in columns by Duncan's multiple range test, $P=0.05$.

NS,*Nonsignificant or significant at $P=0.05$, respectively.

Table 3. The interaction of cultivation and herbicide treatments on weed dry weight in a cowpea crop. ${ }^{z}$

\begin{tabular}{lccrr}
\hline & \multicolumn{4}{c}{ Weed dry wt $\left(\mathrm{g} \cdot \mathrm{m}^{-2}\right)$} \\
\cline { 2 - 5 } Cultivations & No herbicide & Paraquat & Trifluralin & Metolachlor \\
\cline { 2 - 5 } & & \multicolumn{4}{c}{1988} \\
0 & $886 \mathrm{a}$ & $871 \mathrm{a}$ & $11 \mathrm{~d}$ & $32 \mathrm{~d}$ \\
1 & $560 \mathrm{bc}$ & $666 \mathrm{ab}$ & $2 \mathrm{~d}$ & $17 \mathrm{~d}$ \\
2 & $514 \mathrm{bc}$ & $370 \mathrm{c}$ & $<1 \mathrm{~d}$ & $5 \mathrm{~d}$ \\
& & & & \\
0 & $319 \mathrm{~b}$ & $575 \mathrm{a}$ & $<1 \mathrm{c}$ & $<1 \mathrm{c}$ \\
1 & $42 \mathrm{c}$ & $194 \mathrm{bc}$ & $1 \mathrm{c}$ & $0 \mathrm{c}$ \\
2 & $73 \mathrm{c}$ & $84 \mathrm{c}$ & $<1 \mathrm{c}$ & $0 \mathrm{c}$ \\
\hline
\end{tabular}

${ }^{2}$ Mean separation within years by interaction LSD. For 1988, LSD $=$ $252, P=0.01$. For 1989 , LSD $=214, P=0.05$.

no reduction in established cowpea stands at 30 days after planting following a preemergence application of metolachlor at 3.5 $\mathrm{kg} \cdot \mathrm{ha}^{-1}$.

Cultivation had no significant effects on biological yield, seed yield, harvest index, or individual seed weight of cowpeas either year, but cultivation $\times$ herbicide interactions were evident for weed dry weight (Tables 1 and 2). Weed dry weight was unaffected by cultivation in the trifluralin and metolachlor plots in either year (Table 3). One cultivation significantly decreased weed dry weight compared with the uncultivated control in the absence of herbicides in both years, with no further decrease from a second cultivation (Table 3). However, cultivation of the no-herbicide and paraquat plots never reduced weed dry weight as much as the residual herbicides in 1988. In contrast, a single cultivation of the no-herbicide and paraquat plots reduced weed dry weights to values that were not significantly different from those obtained with the residual herbicides in 1989. Paraquat plots had higher or equal weed dry weights than those of corresponding no-herbicide plots in both years (Table 3 ). The paraquat plots did not receive the final preplanning tillage and may have contained a reservoir of late-germinating weed seeds.
Pigweeds were the dominant members of the weed community in these studies. There were no treatment effects on the number of goosegrass plants either year (data not presented); stands averaged $<0.4$ plant $/ \mathrm{m}^{2}$ in 1988 and $<0.1 \mathrm{plant} / \mathrm{m}^{2}$ in 1989. There also were no treatment effects on the number of large crabgrass plants in 1988 (detailed data not presented); stands averaged $<0.2 \mathrm{plant} / \mathrm{m}^{2}$. In 1989 , large crabgrass plants were present only in the control and paraquat plots, with the largest stand being $0.9 \mathrm{plant} / \mathrm{m}^{2}$ in the no-cultivation/no-herbitide control (detailed data not presented).

The main effects of the no-herbicide and paraquat treatments were similar for all measured horticultural variables in 1988 (Table 1). The potential weed pressure (dry-weight basis) was $886 \mathrm{~g} \cdot \mathrm{m}^{-2}$ in 1988 (Table 3), and plots without residual herbicides averaged four pigweeds per square meter (Table 1). The control and paraquat plots were so infested with weeds in 1988 that mechanical harvest would have been impossible and hand harvest impractical. A grower would have abandoned a field that badly infested with weeds. The residual herbicides, in contrast, provided excellent weed control and more than tripled cowpea seed yield compared with that obtained without an herbicide (Table 1). There were no differences in weed control or cowpea yield between trifluralin and metolachlor in 1988.

The no-herbicide and paraquat treatments again gave similar results for most horticultural variables in 1989 (Table 2). However, the potential weed pressure (dry-weight basis) was only $319 \mathrm{~g} \cdot \mathrm{m}^{-2}$ in 1989 , or less than half that of 1988 (Table 3). As a result, there were fewer significant differences among the herbicide treatments in 1989 than in 1988 (Table 2). Main effects of the residual herbicides were nonsignificant for cowpea biological or seed yield compared with plants grown without an herbicide in 1989. Harvest indices were increased by the residual herbicides in 1989, possibly due to reduced weed pressure in the residual herbicide plots (at least in the absence of cultivation), less cowpea plant-to-plant competition resulting from the slightly reduced cowpea stands in the residual herbicide plots, or a combination of these factors.

Economic aspects. Basic operating budgets for the no-cultivation/no-herbicide treatment (hereafter called "control") showed 
Table 4. Operating budgets for cowpeas grown with no cultivation and no herbicide.

\begin{tabular}{|c|c|c|c|c|c|}
\hline \multirow[b]{2}{*}{ Items } & \multirow[b]{2}{*}{ Price $(\$) /$ unit } & \multicolumn{2}{|c|}{1988} & \multicolumn{2}{|c|}{1989} \\
\hline & & Quantity & $\begin{array}{c}\text { Value } \\
(\$)\end{array}$ & Quantity & $\begin{array}{c}\text { Value } \\
(\$)\end{array}$ \\
\hline \multicolumn{6}{|l|}{ Operating inputs } \\
\hline Plow & 22.25/ha & 1.00 & 22.25 & 1.00 & 22.25 \\
\hline Harrow & $17.30 / \mathrm{ha}$ & 1.00 & 17.30 & 1.00 & 17.30 \\
\hline Final tillage & $12.35 / \mathrm{ha}$ & 1.00 & 12.35 & 1.00 & 12.35 \\
\hline Nitrogen & $0.37 / \mathrm{kg}$ & 34.00 & 12.58 & 34.00 & 12.58 \\
\hline Cowpea seed & $3.20 / \mathrm{kg}$ & 29.10 & 93.12 & 43.70 & 140.00 \\
\hline Planting & $12.35 / \mathrm{ha}$ & 1.00 & 12.35 & 1.00 & 12.35 \\
\hline Irrigation & $7.79 / \mathrm{ha}$ per $\mathrm{cm}$ & 8.50 & 66.21 & 5.50 & 42.85 \\
\hline Methomyl & 10.58/liter & 2.34 & 24.76 & 7.00 & 74.06 \\
\hline Spray methomyl & $7.40 / \mathrm{ha}$ & 1.00 & 7.40 & 2.00 & 14.80 \\
\hline Total preharvest costs/ha & & \multicolumn{2}{|c|}{$\$ 268.00$} & \multicolumn{2}{|c|}{$\$ 348.00$} \\
\hline Operating capital & $0.025 / \$$ & 268.00 & 6.71 & 348.00 & 8.71 \\
\hline Custom harvest & $39.55 / \mathrm{ha}$ & 1.00 & 39.55 & 1.00 & 39.55 \\
\hline Custom hauling & $4.40 / \mathrm{Mg}$ & 0.29 & 1.28 & 1.29 & 5.68 \\
\hline Total operating costs/ha & & \multicolumn{2}{|c|}{$\$ 315.00$} & \multicolumn{2}{|c|}{$\$ 401.00$} \\
\hline Income (cowpeas) & $600.00 / \mathrm{Mg}$ & 0.29 & 174.00 & 1.29 & 774.00 \\
\hline $\begin{array}{l}\text { Income above total } \\
\text { operating costs/ha }\end{array}$ & & \multicolumn{2}{|c|}{$-\$ 141.00$} & \multicolumn{2}{|c|}{$\$ 373.00$} \\
\hline
\end{tabular}

Table 5. Seed yields from cowpeas grown with selected weed control treatments compared with seed yields from cowpeas grown with no herbicide and no cultivation. ${ }^{2}$

\begin{tabular}{lcccc}
\hline & & \multicolumn{2}{c}{ Seed yield $\left(\mathrm{Mg} \cdot \mathrm{ha}^{-1}\right)$} \\
\cline { 5 - 6 } & \multicolumn{2}{c}{ Treatment } & & \multicolumn{2}{c}{ Year } \\
\cline { 5 - 6 } Herbicide & Cultivations & & 1988 & 1989 \\
\hline None & 0 & $0.29 \mathrm{~b}$ & $1.29 \mathrm{c}$ \\
Trifluralin & 1 & $0.54 \mathrm{~b}$ & $1.51 \mathrm{bc}$ \\
& 0 & $1.76 \mathrm{a}$ & $1.83 \mathrm{ab}$ \\
Metolachlor & 1 & $1.58 \mathrm{a}$ & $1.92 \mathrm{ab}$ \\
& 0 & $1.58 \mathrm{a}$ & $1.77 \mathrm{ab}$ \\
& 1 & $1.61 \mathrm{a}$ & $2.09 \mathrm{a}$ \\
\hline
\end{tabular}

${ }^{2}$ Mean separation within years by LSD, $P=0.05$. For 1988 , LSD $=$ 0.38 . For 1989 , LsD $=0.43$.

that this strategy would have resulted in a loss to the grower of $\$ 141 /$ ha in 1988 but a profit of about $\$ 370 /$ ha in 1989 (Table 4 ). Further analyses of individual treatments by LSD (not presented) showed only one case where a treatment not involving a residual herbicide produced a significant $(P=0.05)$ seed yield increase over the control. In 1988, use of paraquat plus two cultivations led to a yield increase of $0.46 \mathrm{Mg} \cdot \mathrm{ha}^{-1}$ and a net income increase of $\$ 221.46 /$ ha compared with the control. In the remaining cases, use of paraquat would have reduced net income by $\$ 34.79 /$ ha compared with the control (partial budgets for paraquat not presented). Thus, under the conditions of this study, paraquat usually was not cost effective when used with the stale seedbed weed control technique.

A single cultivation without use of an herbicide resulted in yields similar to those obtained from the control in both years (Table 5). Thus, this strategy would have reduced net income by $\$ 12.66 /$ ha $(\$ 12.35 /$ ha for cultivation plus $\$ 0.31$ operating capital) compared with the control. Also, the other horticultural data (Tables 1 and 2) showed no benefit from a second cultivation, supporting a report that the critical period for weed competition in cowpea is during the first 30 days of crop growth (Bhan et al., 1982).

Treatments involving the residual herbicides resulted in in- creased yields compared with the control, but there were no significant yield differences attributable to the presence of a supplementary cultivation (Table 5). Therefore, a single mean yield obtained from the four residual herbicide treatments shown in Table 5 was used within each year for entry into the partial budgets (Table 6). The partial budgets showed that all four residual herbicide treatments were profitable in both years. Since cultivation added expenses without significantly increasing yield, and since metolachlor had a higher total cost than trifluralin, trifluralin without cultivation had the greatest profit potential.

A profit of about $\$ 370 /$ ha was possible with the no-cultivation/no-herbicide strategy in 1989 (Table 4). However, commercial yields in these control plots probably would have been substantially lower than those reported here. All available cowpea seed yield was gathered by hand in these studies, regardless of the presence of weeds. Commercially, mechanical harvest is commonly used. Tall weeds, such as redroot pigweed, interfere with efficient mechanical harvest, and the control plots contained an average of $319 \mathrm{~g} \cdot \mathrm{m}^{-2}$ of weed dry weight in 1989 (Table 3). Thus, a grower almost certainly would have employed some type of weed control. A single cultivation, without an herbicide, reduced the average weed dry weight to $42 \mathrm{~g} \cdot \mathrm{m}^{-2}$ in 1989 (Table 3) but did not significantly increase seed yields over the control (Table 5). In contrast, the use of trifluralin without cultivation did increase seed yields and would have increased potential profits by $93 \%$ over the control.

Mechanical cultivation was of limited benefit as a weed control strategy in narrow-row $(55 \mathrm{~cm})$ cowpeas in these studies. Supplementing a residual herbicide with one or two cultivations did not result in significant reductions in weed dry weight or significant increases in cowpea seed yield compared with the use of a residual herbicide alone.

The residual herbicides trifluralin and metolachlor provided excellent weed control in these studies. The use of residual herbicides was the most profitable weed control strategy for cowpea production in 1988, when potential weed pressure (dryweight basis) was $886 \mathrm{~g} \cdot \mathrm{m}^{-2}$ Residual herbicides did not always increase cowpea seed yield over that obtained using cultivation alone in 1989. Potential weed pressure (dry-weight basis) was only $319 \mathrm{~g} \cdot \mathrm{m}^{-2}$ in 1989 , and the residual herbicides gave 
Table 6. Partial budgets showing changes in cowpea net returns per hectare for alternative cultivation and herbicide treatments. ${ }^{2}$

\begin{tabular}{|c|c|c|c|c|c|c|c|c|c|}
\hline \multirow[b]{2}{*}{ Items } & \multirow[b]{2}{*}{ Price $(\$) /$ unit } & \multicolumn{2}{|c|}{ Trifluralin } & \multicolumn{2}{|c|}{$\begin{array}{l}\text { Trifluralin }+ \\
\text { one cultivation }\end{array}$} & \multicolumn{2}{|c|}{ Metolachlor } & \multicolumn{2}{|c|}{$\begin{array}{l}\text { Metolachlor }+ \\
\text { one cultivation }\end{array}$} \\
\hline & & Quantity & $\begin{array}{c}\text { Value } \\
(\$)\end{array}$ & Quantity & $\begin{array}{l}\text { Value } \\
(\$)\end{array}$ & Quantity & $\begin{array}{c}\text { Value } \\
(\$)\end{array}$ & Quantity & $\begin{array}{l}\text { Value } \\
(\$)\end{array}$ \\
\hline \multicolumn{10}{|l|}{ Added expense (AE) } \\
\hline Cultivation & $12.35 / \mathrm{ha}$ & 0.00 & 0.00 & 1.00 & 12.35 & 0.00 & 0.00 & 1.00 & 12.35 \\
\hline Spray herbicide & $7.40 / \mathrm{ha}$ & 1.00 & 7.40 & 1.00 & 7.40 & 1.00 & 7.40 & 1.00 & 7.40 \\
\hline Trifluralin & $17.64 / \mathrm{kg}$ & 0.56 & 9.88 & 0.56 & 9.88 & 0.00 & 0.00 & 0.00 & 0.00 \\
\hline Custom hauling, 1988 & $4.40 / \mathrm{Mg}$ & 1.34 & 5.91 & 1.34 & 5.91 & 1.34 & 5.91 & 1.34 & 5.91 \\
\hline Custom hauling, 1989 & $4.40 / \mathrm{Mg}$ & 0.61 & 2.70 & 0.61 & 2.70 & 0.61 & 2.70 & 0.61 & 2.70 \\
\hline \multicolumn{10}{|l|}{ Reduced income (RI): None } \\
\hline Total AE \& RI/ha, 1988 & & 1.00 & 23.62 & 1.00 & 36.28 & 1.00 & 41.02 & 1.00 & 53.68 \\
\hline Total AE \& RI/ha, 1989 & & 1.00 & 20.41 & 1.00 & 33.07 & 1.00 & 37.81 & 1.00 & 50.47 \\
\hline \multicolumn{10}{|l|}{ Added income $(\mathrm{AI})^{\mathrm{y}}$} \\
\hline Total AI \& RE/ha, 1989 & & 1.00 & 367.00 & 1.00 & 367.00 & 1.00 & 367.00 & 1.00 & 367.00 \\
\hline \multicolumn{10}{|l|}{ Net income change/ha from no } \\
\hline cultivation/no herbicide, 1988 & & 1.00 & 782.00 & 1.00 & 769.00 & 1.00 & 764.00 & 1.00 & 752.00 \\
\hline \multirow{2}{*}{\multicolumn{2}{|c|}{$\begin{array}{l}\text { Net income change/ha from no } \\
\text { cultivation/no herbicide, } 1989\end{array}$}} & & & & & & & & \\
\hline & & 1.00 & 347.00 & 1.00 & 334.00 & 1.00 & 330.00 & 1.00 & 317.00 \\
\hline
\end{tabular}

${ }^{2}$ This table shows the changes required to convert the operating budgets for the no-cultivation/no-herbicide controls in the respective years (Table 4) to operating budgets for selected cultivation and herbicide treatments. The same values were used for cultivation, spraying, trifluralin, metolachlor, and operating capital in both years. Also, there was no reduced income or reduced expense in both years because none of the treatments presented in this table resulted in yields that were lower than those obtained with no cultivation and no herbicide. Treatments involving paraquat or two cultivations generally were not cost effective (see text) and are not presented in this table.

yCowpea yields shown in this table represent added output above yields (shown in Tables 4 and 5) for the no-cultivation/no-herbicide controls in the respective years. Yields from the four treatments presented in this table were significantly $(P=0.05)$ higher than yields obtained with no cultivation and no herbicide, but there were no significant $(P=0.05)$ yield differences among the four treatments (Table 5). Therefore, a single mean yield obtained from the four treatments was used within each year for these partial budgets.

slight but significant reductions in cowpea stands. Nevertheless, the use of trifluralin or metolachlor increased net income compared with the no-cultivation/no-herbicide control, whereas the use of cultivation alone did not.

We conclude that with present production practices, the use of the residual herbicides trifluralin or metolachlor for cowpea weed control is likely to be economically and horticulturally justified, even in a season with relatively low weed pressure. Growers presently have no good way to predict weed pressure in advance of planting, and mechanical cultivation may not provide adequate weed control if weed infestations are heavy. If herbicide usage is to be reduced, it would seem necessary to implement an integrated management system that reduces potential weed pressure and increases the efficiency of cultivation. Steps toward such a system could include crop diversification, rotation, timing of planting to give the crop a competitive advantage, and unconventional soil management systems such as ridge tillage. (Akinyemiju and Echendu, 1987; National Research Council, 1989).

\section{Literature Cited}

Akinyemiju, O.A. and T.N.C. Echendu. 1987. Influence of different tillage methods and pre-emergence herbicides on weed control in cowpea [Vigna unguiculata (L.) Walp.]. Crop Protection 6:289-294.

Akobundu, I.0. 1982. Weed control in cowpea (Vigna unguiculata) in the humid tropics. Weed Sci. 30:331-334.

Bhan, V.M., R.S. Balyan, and S.P. Singh. 1982. Influence of time of weed removal and weed species on the grain yield of cowpea. Indian J. Agron. 27:267-271.

Glaze, N.C. 1970. Evaluation of herbicides on southern peas. Proc. Southern Weed Sci. Soc. 23:192-194.

National Research Council. 1989. Alternative agriculture. Comm. Role Alternative Farming Methods in Modern Production Agr., Board on Agr. National Academy Press, Washington, D.C.

Ofuya, T.I. 1989. Effect of weed removal regimes on post-flowering insect damage and grain yield of cowpea, Vigna unguiculata (L.) Walp., in a rainforest area of Nigeria. Trop. Agr. (Trinidad) 66:142-144.

Standifer, L.C. and C.E. Beste. 1985. Weed control methods for vegetable production with limited tillage, p. 93-100. In: A.F. Wiese (cd.). Weed control in limited-tillage systems. Weed Sci. Soc. Amer., Champaign, 111. Monogr. no. 2. 